\title{
The Impact of Light Pollution on Islamic New Moon (hilal) Observation
}

\author{
Nur Nafhatun Md Shariff ${ }^{1,3, *}$, Zety Sharizat Hamidi ${ }^{2,3}$, Muhamad Syazwan Faid ${ }^{1}$ \\ ${ }^{1}$ Academy of Contemporary Islamic Studies, Universiti Teknologi MARA, Shah Alam, \\ 40450, Malaysia \\ ${ }^{2}$ Faculty of Applied Sciences, Universiti Teknologi MARA, Shah Alam, 40450, Malaysia \\ ${ }^{3}$ Institute of Science, Universiti Teknologi MARA, 40450, Shah Alam, Selangor, \\ Malaysia
}

Received 05 December 2016, Accepted 08 February 2017

\begin{abstract}
Muslims has differentiated between new moon and Islamic new moon (hilal). The determination of first day of months based on visibility of Islamic new moon (hilal) i.e. sightings of the first sliver of the waxing moon marking the start of each month. One major issue that has affected hilal visibility for many years is misdirected, excessive and obtrusive artificial light. The objective of this research is to study the impact of light pollution on the visibility of hilal. The data were taken using Sky Quality Meter (SQM) which records the visual magnitudes per square arcsecond (mpsas) to measure sky limiting magnitude. Result showed that reading between 16-22 mpsas, the chances to witness hilal is high. Any lower than 16mpsas, the hilal is not visible. The main result of this research is to find out a vital parameter of hilal observations which leads to propose a new criterion i.e. sky limiting magnitude.
\end{abstract}

Keywords: light pollution, Islamic New Moon, hilal, night sky brightness, Sky Quality Meter (SQM).

\section{Introduction}

Due to religious obligation, Muslims has differentiated between new moon and Islamic new moon (hilal). This is based on Quranic verse: "They ask you about the crescent moons; say they are a means to measure your specific times (mawaqit) and are also for the commencement of the hajj” (2: 189). Islamic calendar is regulated by the first appearance of the lunar crescent. Therefore, the observation to determine the month began with the first sighting of the crescent moon - sliver of the waxing moon - on the day 29th [1]. If the crescent moon is seen at western sky after sunset, the new month begins on the next day [2, 3]. If the crescent moon is not seen due to the sky was cloudy etc., the calendar would be assuming a fixed number of days for the month just completed [4] either 29 or 30 days and never 31 days.

The thin crescent (Ar. hilal) can possibly be seen in hours pass after the conjunction in the first phase of the Moon which term as “moon's age” [5, 6]. The word hilal means the first light of the Moon when people actually see the crescent at the outset of a month [7]. The conjunction occurs when moon and sun have the same elliptical longitude or in other word is in conjunction [8]. Conjunction is only an apparent phenomenon due to the

\footnotetext{
* Shariff NNM, Tel.: +60-35544-8262.

E-mail address: nur.nafhatun.ms@gmail.com
} 
perspective. At this point, we cannot see the Moon because we cannot see the reflected sunlight on the Moon's surface - Fig. 1 .

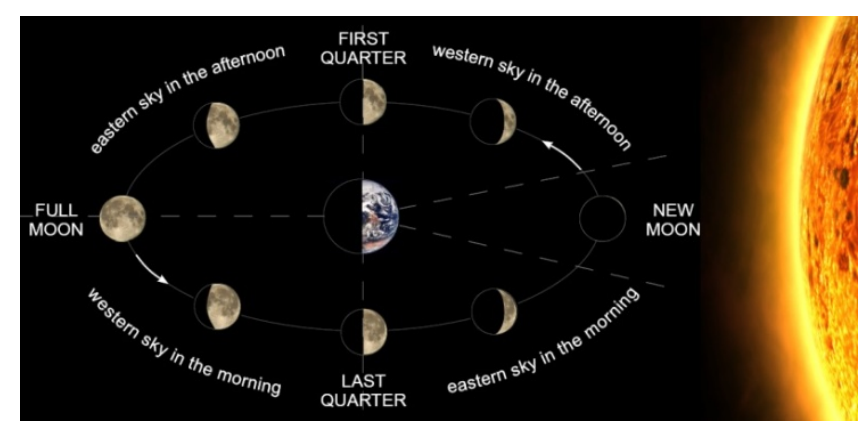

Fig. 1. Phases of the Moon (Credit to Google Image)

Astronomers such as al-Khwarizmi, knew that the determination of the possibility of sighting on a given day was a complicated mathematical problem. Thus it is vital to understand the positions of the Sun and the Moon and the mathematical investigation of the positions of the both celestial bodies relative to each other and to the local horizon [4]. In short, certain criteria required to assure crescent visibility on most occasions can be determined by observation. By combining several criteria, there are three basic methodology that in determining the month: 1) physical sighting or naked eye observation (rukyah); 2) astronomical/calculation basis (hisab falak); and 3) physico-astronomical basis (imkan al-rukyah which lit. possible of visibility by observation) [9].

Before 1970, Malaysia adopted rukyah method in determining the beginning of month [10]. Malaysia then opted to choose imkan al-rukyah method in 1992 until present time [11]. Basically, imkan al-rukyah has three (3) criteria: 1) > 2o of Moon's altitude; AND 2) > 30 of Moon-Sun elongation; OR 3) minimum of eight (8) hours of Moon's age - Figure 2.

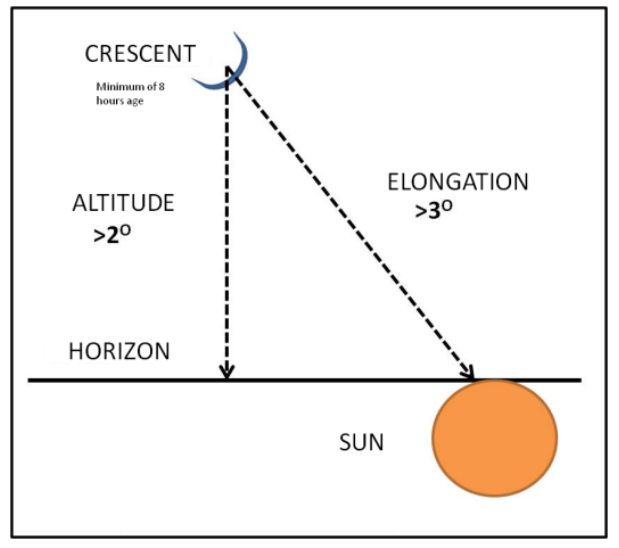

Fig. 2. Imkan al-rukyah method

It is important to note that, it is possible to calculate when this thin crescent will theoretically be visible, but many Muslims will only accept visual confirmation [12]. Figure 3 shows the elusive thin crescent of Sha'ban $1431 \mathrm{H}$ was visible with 1) Moon's altitude: 1041'48”; 2) Elongation: 8.5o; and 3) Moon’s age: 16:09 hours. Although the Moon's altitude did not meet the imkan al-rukyah criteria but Moon's age surpass the minimum of eight (8) hours, thus, the next day was considered new month. 


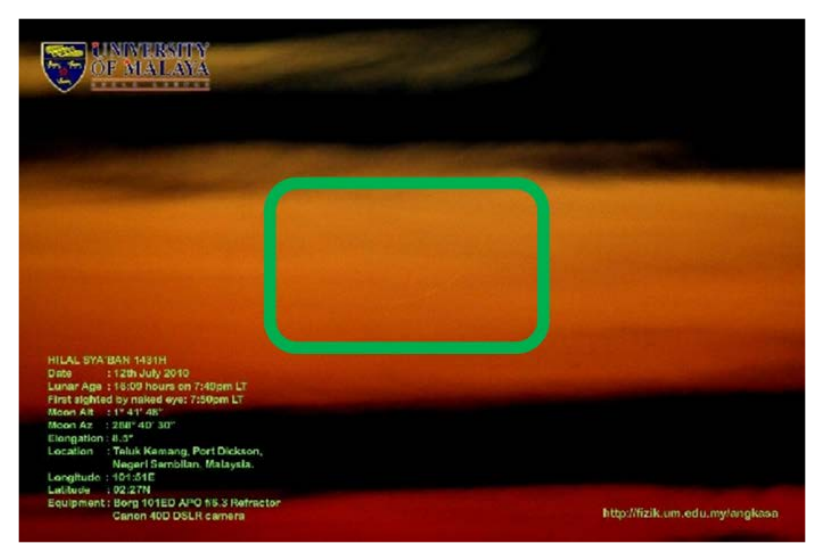

Fig. 3. The elusive thin crescent of Sha'ban $1431 \mathrm{H}$

Since there was no study on sky limiting magnitude at site in Table 1, we hypothesized that light pollution really has impact on the crescent observation which is based on hilal observation report from 1972-2015 by JAKIM (Malaysia Department of Islamic Development), before 1990, the hilal was more frequently seen in 29th day. After 1990, the hilal was frequently seen in 30th day - Table 1 [13].

Table 1. Part of JAKIM observation report

\begin{tabular}{|c|c|c|c|c|c|c|c|}
\hline No & Date* & Date $^{* *}(\mathrm{H})$ & Altitude & Elongation & Moon's Age & Relative Azimuth & Site \\
\hline 1 & 6-Nov-72 & 29 Ramadan 1392 & 1.227 & 5.853 & 9.73 & 5.595 & Telok Kemang \\
\hline 2 & 26-Oct-73 & 29 Ramadan 1393 & 0.564 & 5.302 & 7.96 & 5.209 & Telok Kemang \\
\hline 3 & 16-Nov-74 & 29 Ramadan 1394 & 26.402 & 28.313 & 58.08 & 7.762 & Telok Kemang \\
\hline 4 & 24-Sep-76 & 29 Ramadan 1394 & 5.298 & 8.337 & 15.64 & 5.757 & Telok Kemang \\
\hline 5 & 16-Apr-80 & 1 Jak 1400 & 13.649 & 18.253 & 31.78 & 0.893 & Telok Kemang \\
\hline 6 & 15-May-80 & 29 Jamadilawal 1400 & 11.882 & 13.172 & 24.36 & 3.14 & Pulau Sayak \\
\hline 7 & 15-May-80 & 29 Jamadilawal 1400 & 11.908 & 13.002 & 24.06 & 2.094 & Pontian Kecil \\
\hline 8 & 15-May-80 & 29 Jamadilawal 1400 & 12.039 & 13.066 & 24.2 & 2.319 & Telok Kemang \\
\hline 9 & 15-May-80 & 29 Jamadilawal 1400 & 11.908 & 13.002 & 23.15 & 2.094 & Johor Bahru \\
\hline 10 & 9-Nov-80 & 1 Muh 1401 & 11.896 & 17.456 & 38.57 & 0.697 & Telok Kemang \\
\hline 11 & 1-Aug-81 & 29 Ram 1401 & 14.72 & 15.929 & 31.57 & 3.194 & Telok Kemang \\
\hline 12 & 11-Jul-83 & 29 Ram 1403 & 12.093 & 12.983 & 23.13 & 0.59 & Telok Kemang \\
\hline 13 & 29-Jun-84 & 29 Ram 1404 & 3.051 & 4.498 & 8.38 & 2.555 & Telok Kemang \\
\hline 14 & 6-May-89 & 29 Ramadan 1409 & 7.412 & 13.863 & 23.91 & 7.369 & Pantai Acheh \\
\hline 15 & 6-May-89 & 29 Ramadan 1409 & 2.777 & 13.958 & 24.09 & 7.58 & Bkt. Sg. Besi \\
\hline 16 & 6-May-89 & 29 Ramadan 1409 & 6.84 & 13.803 & 23.74 & 8.018 & Telok Kemang \\
\hline 17 & 6-May-89 & 29 Ramadan 1409 & 6.851 & 13.862 & 23.89 & 7.572 & Pasir Panjang \\
\hline 18 & 6-May-89 & 29 Ramadan 1409 & 9.647 & 13.696 & 23.58 & 7.439 & Pulau Perhentian \\
\hline 19 & 6-May-89 & 29 Ramadan 1409 & 2.398 & 13.492 & 23.26 & 6.922 & W.P. Labuan \\
\hline
\end{tabular}

Recent study showed Telok Kemang light pollution level has getting worsen due to artificial light [14]. One major issue that has affected hilal visibility for many years is misdirected, excessive and obtrusive artificial light. The unwanted light is what we called as light pollution and it is unavoidable as well. Nowadays, people are concerned about the environment but find other issues more important. Due to that, people are not aware enough of light pollution although light pollution does have impacts. Light pollution may appear to cause no direct harm 
to the environment like other forms of pollution but it has a tremendous impact towards human health, nocturnal creatures and not to mention night sky heritage - which is very important for optical astronomy. Moreover, light pollution is a form of waste (electric energy) that eventually contributes to the environmental degradation [15].

From astronomical perspective, limiting magnitude is the faintest apparent magnitude of a celestial body that is detectable or detected by a given instrument. Therefore, the objective of this research is to measure the value of sky limiting magnitude during the crescent observation as we believe sky limiting magnitude has influence over the visibility of hilal. The visibility of new moon is a function primarily of the angle between the moon, observer, and sun (which affects the brightness of the crescent) and the apparent altitude of the moon above the horizon and of the sun below the horizon (which affects the background brightness against which the moon is to be observed).

\section{Methodology}

To conduct this research, we choose west-facing sites - because the hilal sets at west. The sites are: 1) Telok Kemang, Malaysia; 2) Kuala Lumpur, Malaysia; and 3) Coonabarabran, Australia. The data were taken using Sky Quality Meter (SQM; to be specific SQM-LU) which records the visual magnitudes per square arcsecond (mpsas) to measure sky limiting magnitude. The SQM was pointed to horizon in order to get magnitude value of sky with hilal in the measurement cone, we believe the albedo of crescent is very minuscule - Fig. 4. Measurements of the limiting magnitude were made at least one hour before and after the Moon set on dates spread over a period of six months.

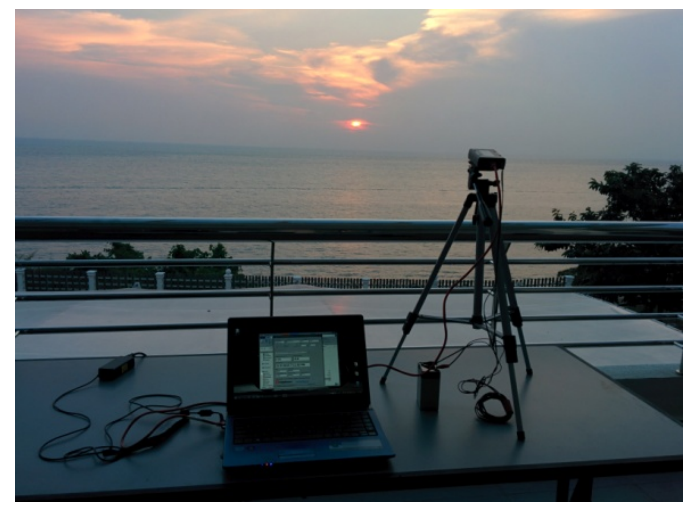

Fig. 4. Data taking using Sky Quality Meter (SQM) during the observation at twilight

\section{Result and Discussion}

Table 2 below is the preliminary results of this research which is the sky limiting magnitude threshold for the hilal to be witnessed. The given readings imply that reading within that range, there is high possibility to witness the hilal because the hilal quickly set depending on Moon's altitude (normally very low) during observation. On the other hand, reading with less than 16 mpsas, the hilal was not visible during the observation.

Table 2. Limiting magnitude threshold

\begin{tabular}{ccc}
\hline NO. & SITE & READING (in mpsas) \\
\hline 1. & Telok Kemang, Malaysia & $16-19$ \\
2. & Kuala Lumpur, Malaysia & $16-18$ \\
3. & Coonabarabran, Australia & $16-22$ \\
\hline
\end{tabular}




\section{Conclusion}

Although it is a long way to go, based on the result, we hope that sky limiting magnitude can be a new criterion in determining new month in Islamic calendar. This research helps us to understand the phenomenon better about the threshold of sky limiting magnitude for hilal.

\section{Acknowledgment}

The authors wish to thank the referee for comments and suggestions to improve the paper. This work was partially supported by RAGS/1/2014/SSI03UITM//2 (MOE) and Universiti Teknologi MARA. Special thanks to JAKIM for generously providing the data.

\section{References}

[1] Zainal, B. (2002). Pengenalan Ilmu Falak, Dewan Bahasa dan Pustaka, Kuala Lumpur.

[2] Odeh, M. S. (2004). New criterion for lunar crescent visibility. Experimental astronomy, 18(1-3), 39-64.

[3] Shariff, N.N.M., Hamidi, Z.S., Muhammad, A., Zainuddin, \& M.Z., Ibrahim, Z.A. (2013). Background theory of twilight in Isha' and Subh prayer, Dimensi Penyelidikan Astronomi Islam, Universiti Malaya, Kuala Lumpur, 121-132.

[4] King, D. A. (2015). Astronomy in the service of Islam. In Handbook of Archaeoastronomy and Ethnoastronomy (pp. 181-196). Springer New York.

[5] Özlem, A. (2014). A simplified crescent visibility criterion. from http://www.icoproject.org/pdf/ ozlem_2014.pdf

[6] Ahmed, A.K.,\& Aziz,A.H.A. (2014). Young moon visibility criterion based on crescent illumination and sky brightness contrast model, Middle-East Journal of Scientific Research, 21(9).

[7] Yusuf, H. (2008). Cesarean moon births: calculations, moon sighting, and the prophetic way, Zaytuna Institute,

[8] Meeus, J. H. (1991). Astronomical algorithms. Willmann-Bell, Incorporated.

[9] Ilyas, M. (1997). Sistem kalendar Islam dari perspektif astronomi. Dewan Bahasa dan Pustaka.

[10] Shariff, N.N.M. (2005). Menentusahkan kriteria imkanur rukyah: Menurut pandangan syarak dan astronomi, Falak Syar'ii, University of Malaya, Kuala Lumpur.

[11] Nawawi, M., Saiful, M., Ismail, K., Abdul Wahab, R., Zaki, A., Huda, N., \& Abdul Niri, M. (2012). Kesan Penggunaan Hitungan Astronomi Dan Alatan Moden Dalam Cerapan Hilal Di Malaysia: Satu Penelitian. Jurnal Fiqh, 9.

[12] Aron, J. (2014). Moon's radio glow could keep Muslim calendars in sync, New Scientist.

[13] JAKIM. (2015). Laporan Kenampakan Hilal, JAKIM (Ed.), Putrajaya.

[14] Faid, M. S., Husien, N., Shariff, N. N. M., Ali, M. O., Hamidi, Z. S., Zainol, N. H., \& Sabri, S. N. U. (2016, May). Monitoring the Level of Light Pollution and Its Impact on Astronomical Bodies Naked-Eye Visibility Range in Selected Areas in Malaysia Using the Sky Quality Meter. In Industrial Engineering, Management Science and Application (ICIMSA), 2016 International Conference on (pp. 1-6). IEEE.

[15] Pun, C. S. J., \& So, C. W. (2012). Night-sky brightness monitoring in Hong Kong. Environmental monitoring and assessment, 184(4), 2537-2557. 